\title{
Islam and Literalism
}

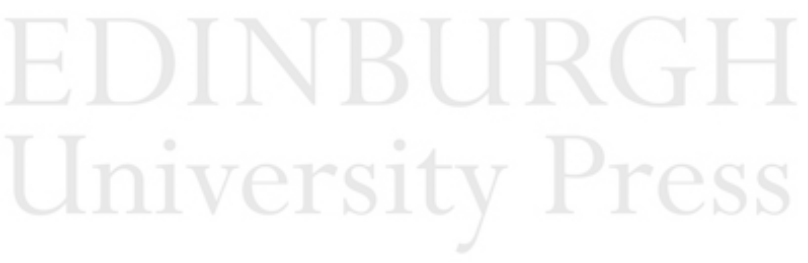


People often say “Be Quiet!", but they don't tell you how long to be quiet for. Or you see a sign which says, KEEP OFF THE GRASS but it should say KEEP OFF THE GRASS AROUND THIS SIGN or KEEP OFF ALL THE GRASS IN THIS PARK because there is lots of grass you are allowed to walk on.

(Christopher John Francis Boone) 


\title{
Islam and Literalism
}

Literal Meaning and Interpretation in Islamic Legal Theory

\author{
Robert Gleave
}

EDINBURGH

University Press 


\section{For Joshua}

\section{Our live-in literalist}

(C) Robert Gleave, 2012, 2013

First published in hardback in 2012 by

Edinburgh University Press Ltd 22 George Square, Edinburgh EH8 9LF www.euppublishing.com

This paperback edition 2013

Typeset in Times Beyrut Roman by 3btype.com, and printed and bound in Great Britain by CPI Group (UK) Ltd, Croydon CR0 4YY

A CIP record for this book is available from the British Library

ISBN 9780748625703 (hardback)

ISBN 9780748689866 (paperback)

ISBN 9780748631131 (webready PDF)

ISBN 9780748655540 (epub)

The right of Robert Gleave to be identified as author of this work has been asserted in accordance with the Copyright, Designs and Patents Act 1988 and the Copyright and Related Rights Regulations 2003 (SI No. 2498).

Epigraph taken from: Mark Haddon, The Curious Incident of the Dog in the Night (London, 2003), p. 39. 